\title{
Protein patterns and their association with photosynthetic pigment content, agronomic behavior, and origin of purslane accessions (Portulaca oleracea L.)
}

\author{
DARYUSh TALEI ${ }^{1 *}$, AMIR MOHAMMAD NAJI ${ }^{2}$ \\ ${ }^{1}$ Medicinal Plants Research Center, Shahed University, Tehran, Iran \\ ${ }^{2}$ Department of Biotechnology, Agriculture Faculty, Shahed University, Tehran, Iran
}

\begin{abstract}
In this study, the proteomic, morphometric, and photosynthetic pigment data of purslane (Portulaca oleracea) accessions were combined together to show their impact on genetic variation in order to establish a relationship between protein patterns and phenotypic behavior of the plant. Seeds of 18 collected purslane accessions were cultivated based on a completely randomized design with three replicates. Before the flowering stage, the data on morphology, photosynthetic pigment content, and seed proteins were obtained. The results showed a significant difference among purslane accessions in terms of the most studied agronomic characteristics and the content of photosynthetic pigments and proteins. The cluster analysis of the 18 purslane accessions based on agronomic data, and photosynthetic pigment content, and protein pattern data produced three main clusters. Moreover, the seed protein analysis revealed that the two polymorphic protein bands of size $40 \mathrm{kDa}$ (protein "a") and $30 \mathrm{kDa}$ (protein "b") effectively diversified the agronomic, photosynthetic pigment, and phylogenetic relationships among the purslane accessions. Interestingly, protein "a" was produced in plants growing in low altitude areas and played a suppressive role for TDW, while protein "b" was produced in plants growing in high altitude areas and functioned as an activator agent for this trait. Overall, the outcomes of the present study indicated the presence of high genetic variability $(77.6 \%)$ among the purslane accessions. These findings suggest that these proteins should be sequenced for further proteomic analyses and can be used for hybridization to generate useful recombinants in segregating generations and improve breeding varieties of $P$. oleracea.
\end{abstract}

Key words: chlorophyll, genetic diversity, morphometric, Portulaca oleracea, protein pattern

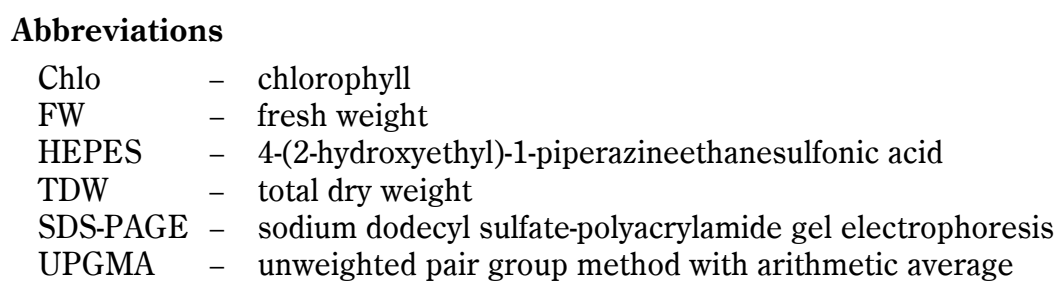

\section{Introduction}

Portulaca oleracea, commonly known as purslane, is an herbaceous herb from the Portulacaceae family. Purslane occurs worldwide, including Europe, America, Canada, India, New Zealand, Australia, China, and Japan (Movahedian et al., 2007). It is particularly well adapted to the warm, moist conditions found in irrigated agricultural and ornamental sites. The plant requires a moist, light-rich, well-drained soil in a sunny area. The plant has a round, smooth, procumbent, succulent stem, with small, oblong, wedge-shaped, sub-sessile, alternate or sub-opposite dark green leaves. The flowers are small, yellow, placed above the last leaves on the branches, and bloom open only for a short time toward the noon. Seeds are reddish brown to black, oval, and tiny (Okafor et al., 2014).

\footnotetext{
* Corresponding author: Medicinal Plants Research Center, Shahed University, Tehran 3319118651, Iran; e-mail: d.talei@shahed.ac.ir
} 
The plant is rich in fatty acids, proteins, and vitamins (mainly vitamins $\mathrm{A}, \mathrm{C}, \mathrm{E}$, and $\mathrm{B}$ and carotenoids) as well as dietary minerals such as magnesium, calcium, potassium, and iron. Approximately $70 \%$ of its fatty acids are unsaturated, and approximately $50 \%$ of these fatty acids comprise only omega-3 fatty acids (Masoodi et al., 2011). According to folk medicine sources, purslane has antinociceptive, anesthetic, antiseptic, antiascorbate, antiinflammatory, anti-fungal, and blood purifying properties; reduces swelling and abscesses; and heals insect bite and scorpion sting (Zhou et al., 2015).

Genetic diversity can be estimated using various methods including morphological traits, protein markers, and molecular markers (Aharizad et al., 2012; Talei et al., 2014). Initially, morphological and agronomic characteristics have often been used for basic genetic characterization (Okpul et al., 2005). However, morphological and agronomical traits have several limitations such as low polymorphism and heritability and may be controlled by epistasis and pleiotropic gene effects ( $\mathrm{Da}-$ naeipour et al., 2019), while biochemical and molecular markers reflect the genotype more directly, independent of environmental impact (Ernst et al., 2017). Biochemical markers and specifically seed protein markers are valuable tools to identify cultivar, register new varieties, and characterize plant species to study genetic diversity (Kutka Hlozakova et al., 2016; Sharma and Krishna, 2017). Most of the proteins are unique and suitable to be used as markers in genetic diversity analyses at interand intra-population levels (Asante et al., 2009). Morphological data could also be used as reliable tools in phylogenetic analysis when they are correlated with biochemical data (Huang et al., 2013). With regard to genetic diversity, several polymorphic proteins have been reported in the genus Mentha (Hassan et al., 2003), Ocimum species (Mustafa et al., 2006), wheat (El-Bakatoushi, 2010), and Brassicaceae (Khurshid and Rabbani, 2012) and purslane (P. oleracea L.) accessions (Alam et al., 2015). The reason for the high variability among purslane in terms of measured traits could be the pursuit of free purslane pollination and the possibility of pollen transfer between the species (Wickramasinghe et al., 2010). Hence, the present research aimed to evaluate seed protein profiles and attempted to utilize them along with morphometric data and photosynthetic pigment data, not only to illustrate genetic diversity but also to discover a relationship among protein patterns, photosynthetic pigments, and morphometric behavior in the herb's accessions. In other words, we assessed whether there is a possibility to detect any specific protein band or bands in relation to a particular photosynthetic pigment and morphometric behavior.

\section{Materials and methods}

\section{Genetic material and growth conditions}

Seeds of 18 accessions of $P$. oleracea were collected from different geographical origins of Iran (Table 1). The seeds were surface sterilized with $10 \%$ sodium hypochlorite $(\mathrm{NaClO})$ solution for $10 \mathrm{~min}$ and thoroughly rinsed with distilled water (Talei et al., 2011). The seeds were cultivated based on a randomized complete block design with three replicates in the research farm of Medicinal Plants Research Center, Shahed University, Tehran, Iran. Each accession was cultivated in $1 \times 1.2 \mathrm{~m}$ plots with three rows and $25 \mathrm{~cm}$ spacing, at the density of $20-30$ plants per plot. The plants were irrigated every 2 days until the flowering stage. Before the flowering stage, 10 plants were randomly selected from each experimental unit, and the data on morphological and photosynthetic pigment traits such as average shoot length $(\mathrm{cm})$, stem diameter $(\mathrm{mm})$, number of branches, shoot fresh weight (FW) (g per plant), shoot dry weight (g per plant), and chlorophyll a $(\mu \mathrm{g} / \mathrm{g} \mathrm{FW})$ and chlorophyll b content ( $\mu \mathrm{g} / \mathrm{g} F W)$ were obtained. The dry shoot weights were measured after drying at $68^{\circ} \mathrm{C}$ for $72 \mathrm{~h}$.

\section{Determination of chlorophyll content}

To determine the content of chlorophyll a, chlorophyll $\mathrm{b}$, and total chlorophyll, approximately $0.5 \mathrm{~g}$ fresh leaf tissue was extracted with $5 \mathrm{ml}$ of $100 \%$ acetone with three replicates. The extracted sample was filtered through a Whatman No. 2 filter paper. The filtrate sample was then centrifuged at $3000 \mathrm{~g}$ for $5 \mathrm{~min}$. Next, $50 \mu \mathrm{l}$ pigment extract was added to $950 \mu \mathrm{l}$ of $80 \%$ aqueous acetone, and the respective absorptions were measured using a Shimadzu UV-1201 model spectrophotometer at 645 and $663 \mathrm{~nm}$ (Arnon, 1967).

\section{Determination of protein content}

To determine the content of seed proteins, $1 \mathrm{~g}$ of collected seeds were grounded in liquid nitrogen using a pre-cooled mortar and pestle to obtain a fine powder, and the powder was then homogenized with $2 \mathrm{ml}$ 
Table1. Geographical origins of the of $P$. oleracea accessions from different parts of Iran

\begin{tabular}{|c|c|c|c|c|}
\hline Code & Region originated & Latitude & Longitude & $\begin{array}{c}\text { Altitude } \\
\text { [m] }\end{array}$ \\
\hline 1 & Varamin & $35^{\circ} 12^{\prime} 36.513^{\prime \prime}$ & $51^{\circ} 40^{\prime} 26.832^{\prime \prime}$ & 842 \\
\hline 2 & Malard & $35^{\circ} 41^{\prime} 29.949^{\prime \prime}$ & $50^{\circ} 50^{\prime} 2.720^{\prime \prime}$ & 1159 \\
\hline 3 & Karaj & $35^{\circ} 49^{\prime} 11.727^{\prime \prime}$ & $50^{\circ} 56^{\prime} 11.296^{\prime \prime}$ & 1282 \\
\hline 4 & Qom & $34^{\circ} 37^{\prime} 35.903^{\prime \prime}$ & $50^{\circ} 55^{\prime} 37.719^{\prime \prime}$ & 911 \\
\hline 5 & Abhar & $36^{\circ} 10^{\prime} 29.042^{\prime \prime}$ & $49^{\circ} 15^{\prime} 20.246^{\prime \prime}$ & 1574 \\
\hline 6 & Zanjan & $36^{\circ} 38^{\prime} 41.781^{\prime \prime}$ & $48^{\circ} 30^{\prime} 54.880^{\prime \prime}$ & 1642 \\
\hline 7 & Qazvin & $36^{\circ} 17^{\prime} 52.241^{\prime \prime}$ & $50^{\circ} 2^{\prime} 41.569^{\prime \prime}$ & 1338 \\
\hline 8 & Bandar Turkman & $36^{\circ} 49^{\prime} 45.880^{\prime \prime}$ & $54^{\circ} 3^{\prime} 19.337^{\prime \prime}$ & -26 \\
\hline 9 & Talesh & $37^{\circ} 52^{\prime} 26.749^{\prime \prime}$ & $48^{\circ} 54^{\prime} 24.150^{\prime \prime}$ & -6 \\
\hline 10 & Hamedan & $34^{\circ} 49^{\prime} 52.081^{\prime \prime}$ & $48^{\circ} 30^{\prime} 56.491^{\prime \prime}$ & 1756 \\
\hline 11 & Razan & $35^{\circ} 23^{\prime} 18.355^{\prime \prime}$ & $49^{\circ} 1^{\prime} 29.424^{\prime \prime}$ & 1839 \\
\hline 12 & Izeh & $29^{\circ} 28^{\prime} 0.801^{\prime \prime}$ & $51^{\circ} 16^{\prime} 18.382^{\prime \prime}$ & 102 \\
\hline 13 & Babol & $36^{\circ} 29^{\prime} 39.799^{\prime \prime}$ & $52^{\circ} 42^{\prime} 25.769^{\prime \prime}$ & 8 \\
\hline 14 & Tonekabon & $36^{\circ} 46^{\prime} 15.806^{\prime \prime}$ & $50^{\circ} 50^{\prime} 49.824^{\prime \prime}$ & 48 \\
\hline 15 & Lourdgan & $30^{\circ} 39^{\prime} 18.529^{\prime \prime}$ & $51^{\circ} 36^{\prime} 53.288^{\prime \prime}$ & 1843 \\
\hline 16 & Boroujerd & $33^{\circ} 52^{\prime} 32.840^{\prime \prime}$ & $48^{\circ} 45^{\prime} 32.557^{\prime \prime}$ & 1533 \\
\hline 17 & Kashan & $33^{\circ} 57^{\prime} 12.852^{\prime \prime}$ & $51^{\circ} 22^{\prime} 9.576^{\prime \prime}$ & 1015 \\
\hline 18 & Folad Shahr & $32^{\circ} 27^{\prime} 55.425^{\prime \prime}$ & $51^{\circ} 24^{\prime} 13.244^{\prime \prime}$ & 1708 \\
\hline
\end{tabular}

of HEPES/KOH extraction buffer as described by Talei et al. (2013). Finally, the Bradford method (1976) was used to determine the total protein concentration using a spectrophotometer at $595 \mathrm{~nm}$ (Lambda 25, UV/VIS). The experiments were performed in triplicate.

\section{Protein separation by SDS-PAGE}

The protein samples were subjected to SDS-PAGE using Laemmli method (1970). Twenty microliters of the protein samples was mixed with $4 \mu$ l loading buffer (0.125 M Tris base, $\mathrm{pH} 6.8 ; 20 \%$ (w/v) glycerol; $2 \%(\mathrm{w} / \mathrm{v})$ SDS; $2 \%(\mathrm{v} / \mathrm{v}) 2$-mercaptoethanol; and $0.01 \%(\mathrm{w} / \mathrm{v})$ bromophenol blue) and loaded into the wells of the $12 \%$ separating gel. Electrophoresis was performed at $100 \mathrm{~V}$ over 90 min by using a Mini Protein electrophoresis system (Bio-Rad, USA).

The gels were stained with $0.25 \%$ Coomassie Brilliant Blue R-250 (Sigma) in 40\% (v/v) methanol and 7\% (v/v) acetic acid for $1 \mathrm{~h}$ and de-stained with $40 \%(\mathrm{v} / \mathrm{v}) \mathrm{me}-$ thanol and 7\% (v/v) acetic acid until the background was clear. Gel scanning and visualization were performed using a densitometer (GS-800, Bio-Rad). The analysis was conducted using UVIDoc Analyzer software.

\section{Statistical analysis}

SPSS v.25 software was used for all statistical analyses, including the raw data normality test and the main data analysis as well as for analysis of variance and Duncan's multiple range test $(P \leq 0.01)$. JMP software version 13 (SAS Institute Inc., 2009b) was used for cluster analysis.

\section{Results}

\section{Analyses of agronomic characteristics and photosynthetic pigments of the purslane accessions}

The variance analysis of the investigated characteristics revealed significant differences among the purslane accessions for most of the studied traits $(P \leq 0.01)$, while no significant differences in stem diameter, number of branches, and root dry weight were observed among the accessions (Tables 2 and 3). These results indicated that the accessions selected for this study 
Table 2. Variance analysis of 18 purslane accessions in terms of agronomic traits

\begin{tabular}{l|c|c|c|c|c|c|c|c}
\hline \multirow{2}{*}{ S.O.V } & \multirow{2}{*}{ df } & \multicolumn{7}{|c}{ Mean square } \\
\cline { 3 - 9 } & & $\begin{array}{c}\text { shoot } \\
\text { length }\end{array}$ & $\begin{array}{c}\text { stem } \\
\text { diameter }\end{array}$ & $\begin{array}{c}\text { branches } \\
\text { number }\end{array}$ & $\begin{array}{c}\text { shoot fresh } \\
\text { weight }\end{array}$ & $\begin{array}{c}\text { shoot dry } \\
\text { weight }\end{array}$ & $\begin{array}{c}\text { root } \\
\text { length }\end{array}$ & $\begin{array}{c}\text { root fresh } \\
\text { weight }\end{array}$ \\
\hline Rep & 2 & $200.0^{* *}$ & $6.3^{\mathrm{ns}}$ & $2.6^{* *}$ & $2864.3^{\mathrm{ns}}$ & $176.6^{\mathrm{ns}}$ & $46.9^{* *}$ & $207.9^{* *}$ \\
\hline Genotype & 17 & $70.8^{*}$ & $3.0^{\mathrm{ns}}$ & $0.4^{\mathrm{ns}}$ & $31588.2^{*}$ & $621.8^{* *}$ & $8.5^{*}$ & $16.6^{\mathrm{ns}}$ \\
\hline Error & 34 & 32.5 & 2.1 & 0.3 & 7484.6 & 216.9 & 4.0 & 4.5 \\
\hline CV [\%] & & 9.0 & 16.0 & 15.9 & 22.8 & 22.2 & 9.47 & 8.9 \\
\hline
\end{tabular}

*, ** - significant at $5 \%$ and $1 \%$ probability level; ns - non-significant

Table 3. Variance analysis of 18 purslane accessions in terms of some agronomic traits, protein and photosynthetic pigments contents

\begin{tabular}{l|c|c|c|c|c|c|c}
\hline \multirow{2}{*}{ S.O.V } & \multirow{2}{*}{ df } & \multicolumn{7}{|c}{ Mean square } \\
\cline { 3 - 8 } & & $\begin{array}{c}\text { root } \\
\text { dry weight }\end{array}$ & $\begin{array}{c}\text { total } \\
\text { dry weight }\end{array}$ & protein & chlorophyll a & chlorophyll b & $\begin{array}{c}\text { total } \\
\text { chlorophyll }\end{array}$ \\
\hline Rep & 2 & $10.3^{* *}$ & $155.9^{\text {ns }}$ & $0.67^{* *}$ & $4.2^{\text {ns }}$ & $181.4^{* *}$ & $240.1^{* *}$ \\
\hline Genotype & 17 & $0.5^{\text {ns }}$ & $618.3^{* *}$ & $0.02^{* *}$ & $17.0^{* *}$ & $64.8^{* *}$ & $78.7^{* *}$ \\
\hline Error & 34 & 0.5 & 218.0 & 0.01 & 4.9 & 13.7 & 26.1 \\
\hline CV [\%] & & 18.7 & 23.8 & 2.3 & 4.4 & 17.9 & 7.1 \\
\hline
\end{tabular}

were significantly different from each other based on photosynthetic pigments and agronomic traits.

The highest $(71.4 \pm 5 \mathrm{~cm})$ and lowest $(49.1 \pm 1.7 \mathrm{~cm})$ shoot length were shown by Abhar accession from the Zanjan state and Bandar Turman accession from the Golestan state, respectively. The highest stem diameter $(10.9 \pm 0.8 \mathrm{~mm})$ was exhibited by Boroujerd accession from the Lorestan state, while the lowest stem diameter $(7.5 \pm 1.1 \mathrm{~mm})$ was shown by Bandar Turkman accession. Talesh and Lourdgan accessions showed the highest $(411.93 \pm 30.1 \mathrm{~g}$ per plant) and lowest shoot FW $(142.6 \pm 15.1 \mathrm{~g}$ per plant), respectively. The highest shoot dry weight $(74.4 \pm 5.4$ g per plant) was shown by Zanjan accession, while the lowest shoot dry weight $(21.7 \pm 3.1$ g per plant) was observed for Foulad shahr accession. No significant differences in root fresh and dry weights were observed among the different accessions; nevertheless, root fresh and dry weights varied from 20.5 to 29.9 and from 3.2 to 4.9 g per plant, respectively, among the different accessions. Table 3 shows the comparison of mean values obtained using Duncan's multiple range test for the studied traits at $P \leq 0.01$.

The results showed significant differences in root length among the accessions, with the variation ranging from 17.7 to $24.3 \mathrm{~cm}$. The highest $(88.8 \pm 6.1 \mathrm{~g}$ per plant) and lowest total dry weight (TDW) $(22.9 \pm 4.1 \mathrm{~g}$ per plant) were observed for Zanjan and Lourdgan accessions, respectively. The highest $(3.3 \pm 0.12 \mathrm{mg} / \mathrm{g} \mathrm{FW})$ and lowest $(3.0 \pm 4.1 \mathrm{mg} / \mathrm{g} \mathrm{FW})$ protein content was shown by Bandar Turkman and Hamadan accessions, respectively. The highest $(53.2 \pm 0.9 \mu \mathrm{g} / \mathrm{g} \mathrm{FW})$ and lowest $(43.3 \pm 3.8 \mu \mathrm{g} / \mathrm{g} \mathrm{FW})$ chlorophyll a content was observed for Zanjan and Bandar Turkman accessions, respectively, while the highest $(28.5 \pm 1.1 \mu \mathrm{g} / \mathrm{g} \mathrm{FW})$ and lowest $(12.4 \pm 4.2 \mu \mathrm{g} / \mathrm{g} \mathrm{FW})$ chlorophyll b content was observed for Qazvin and Zanjan accessions, respectively. The total chlorophyll content varied from 64.6 to $81.1 \mu \mathrm{g} / \mathrm{g} \mathrm{FW}$ among different accessions (Table 4). On the basis of these results, it could be stated that the differences in the measured traits among the accessions can be used for breeding programs and selection of the desired genotypes.

The variance analysis based on 13 states showed significant differences among the accessions in shoot length, shoot fresh and dry weights, TDW, protein content, and chlorophyll content in each state. The highest $(68.1 \pm 4.5 \mathrm{~cm})$ and lowest $(49.1 \pm 1.8 \mathrm{~cm})$ shoot length was observed for the Gilan state and Golestan state, 
Table 4. Mean comparison of different purslane accessions based on some studied traits

\begin{tabular}{|c|c|c|c|c|c|c|c|c|c|}
\hline Genotype & $\begin{array}{c}\text { Shoot } \\
\text { length } \\
{[\mathrm{cm}]}\end{array}$ & $\begin{array}{c}\text { Shoot } \\
\text { fresh weight } \\
{[\mathrm{g}]}\end{array}$ & $\begin{array}{c}\text { Shoot } \\
\text { dry weight } \\
{[\mathrm{g}]}\end{array}$ & $\begin{array}{l}\text { Root length } \\
{[\mathrm{cm}]}\end{array}$ & $\begin{array}{c}\text { Total } \\
\text { dry weight } \\
{[g]}\end{array}$ & $\begin{array}{l}\text { Protein } \\
{[\mathrm{mg} / \mathrm{g} \mathrm{fw}]}\end{array}$ & $\begin{array}{c}\text { Chlorophyll a } \\
{[\mu \mathrm{g} / \mathrm{g} \mathrm{fw}]}\end{array}$ & $\begin{array}{l}\text { Chlorophyll b } \\
{[\mu \mathrm{g} / \mathrm{g} \mathrm{fw}]}\end{array}$ & $\begin{array}{c}\text { Total chlorophyll } \\
{[\mu \mathrm{g} / \mathrm{g} \text { fw }]}\end{array}$ \\
\hline Varamin & $66.3 \pm 1.6^{\mathrm{a}-\mathrm{d}}$ & $330.4 \pm 30.2^{\mathrm{a}-\mathrm{d}}$ & $62.9 \pm 8.4^{\mathrm{ab}}$ & $21.0 \pm 0.6^{\mathrm{a}-\mathrm{e}}$ & $75.1 \pm 8.4^{\mathrm{ab}}$ & $3.2 \pm 0.10^{\mathrm{ab}}$ & $48.2 \pm 2.8^{\mathrm{b}}$ & $16.4 \pm 1.2^{\text {ef }}$ & $64.6 \pm 3.9^{\mathrm{e}}$ \\
\hline Malard & $62.7 \pm 2.2^{\mathrm{a}-\mathrm{c}}$ & $335.5 \pm 53.2^{\mathrm{a}-\mathrm{d}}$ & $60.4 \pm 12.7^{\mathrm{a}-\mathrm{c}}$ & $20.0 \pm 0.6^{\mathrm{c}-\mathrm{e}}$ & $52.7 \pm 13.1^{c-e}$ & $3.3 \pm 0.09^{\mathrm{ab}}$ & $51.9 \pm 0.7^{\mathrm{ab}}$ & $21.0 \pm 2.0^{\mathrm{b}-\mathrm{d}}$ & $73.0 \pm 2.7^{\mathrm{a}-\mathrm{e}}$ \\
\hline Karaj & $65.5 \pm 3.5^{\mathrm{a}-\mathrm{c}}$ & $313.8 \pm 21.7^{\mathrm{a}-\mathrm{d}}$ & $48.6 \pm 3.7^{\mathrm{a}-\mathrm{e}}$ & $22.0 \pm 0.0^{\mathrm{a}-\mathrm{c}}$ & $49.6 \pm 3.8^{\mathrm{c}-\mathrm{e}}$ & $3.1 \pm 0.11^{\mathrm{a}-\mathrm{d}}$ & $52.2 \pm 0.3^{\mathrm{ab}}$ & $25.6 \pm 0.9^{\mathrm{ab}}$ & $77.8 \pm 1.3^{\mathrm{a}-\mathrm{c}}$ \\
\hline Qom & $65.9 \pm 2.9^{\mathrm{a}-\mathrm{c}}$ & $271.3 \pm 61.7^{\mathrm{a}-\mathrm{d}}$ & $53.3 \pm 9.1^{\mathrm{a}-\mathrm{d}}$ & $24.0 \pm 1.5^{\mathrm{ab}}$ & $38.8 \pm 9.5^{\mathrm{d}-\mathrm{g}}$ & $3.2 \pm 0.13^{\mathrm{ab}}$ & $52.4 \pm 0.1^{\mathrm{ab}}$ & $27.7 \pm 1.7^{\mathrm{ab}}$ & $80.0 \pm 1.7^{\mathrm{ab}}$ \\
\hline Abhar & $71.4 \pm 5.0^{\mathrm{a}}$ & $203.3 \pm 19.8^{\mathrm{a}-\mathrm{d}}$ & $49.2 \pm 5.3^{\mathrm{a}-\mathrm{e}}$ & $21.3 \pm 1.3^{\mathrm{a}-\mathrm{e}}$ & $49.9 \pm 6.3^{\mathrm{c}-\mathrm{e}}$ & $3.2 \pm 0.09^{\mathrm{ab}}$ & $52.8 \pm 0.6^{\mathrm{a}}$ & $17.8 \pm 3.0^{\mathrm{c}-\mathrm{e}}$ & $70.6 \pm 2.4^{\mathrm{b}-\mathrm{e}}$ \\
\hline Zanjan & $63.2 \pm 5.6^{\mathrm{a}-\mathrm{c}}$ & $240.2 \pm 51.9^{\mathrm{a}-\mathrm{d}}$ & $74.4 \pm 5.4^{\mathrm{a}}$ & $20.3 \pm 2.0^{\mathrm{a}}$ & $88.8 \pm 6.1^{\mathrm{a}}$ & $3.1 \pm 0.09^{b-d}$ & $53.2 \pm 0.9^{\mathrm{a}}$ & $12.4 \pm 4.2^{\mathrm{f}}$ & $65.6 \pm 3.4^{\text {de }}$ \\
\hline Qazvin & $63.5 \pm 2.1^{\mathrm{a}-\mathrm{c}}$ & $205.9 \pm 7.5^{\mathrm{a}-\mathrm{d}}$ & $42.3 \pm 7.4^{\mathrm{b}-\mathrm{e}}$ & $21.0 \pm 0.6^{\mathrm{a}-\mathrm{e}}$ & $51.8 \pm 7.4^{\mathrm{c}-\mathrm{e}}$ & $3.2 \pm 0.08^{\mathrm{ab}}$ & $52.7 \pm 0.1^{\mathrm{a}}$ & $28.5 \pm 1.1^{\mathrm{a}}$ & $81.1 \pm 1.0^{\mathrm{a}}$ \\
\hline Bandar Turkman & $49.9 \pm 1.7^{\mathrm{d}}$ & $370.8 \pm 80.2^{\mathrm{a}-\mathrm{c}}$ & $60.1 \pm 4.6^{\mathrm{a}-\mathrm{c}}$ & $17.7 \pm 0.3^{\mathrm{e}}$ & $59.9 \pm 4.8^{\mathrm{b}-\mathrm{d}}$ & $3.3 \pm 0.12^{\mathrm{a}}$ & $43.3 \pm 3.8^{c}$ & $24.4 \pm 6.6^{\mathrm{a}-\mathrm{c}}$ & $67.7 \pm 9.4^{\mathrm{de}}$ \\
\hline Talesh & $68.1 \pm 3.8^{\mathrm{ab}}$ & $411.9 \pm 30.1^{\mathrm{a}}$ & $35.9 \pm 17.3^{\mathrm{b}-\mathrm{e}}$ & $21.7 \pm 1.5^{\mathrm{a}-\mathrm{d}}$ & $64.7 \pm 16.6^{\mathrm{bc}}$ & $3.3 \pm 0.14^{\mathrm{a}}$ & $52.8 \pm 0.4^{\mathrm{a}}$ & $15.6 \pm 0.1^{\text {ef }}$ & $68.4 \pm 0.5^{\mathrm{c}-\mathrm{e}}$ \\
\hline Hamedan & $61.4 \pm 7.5^{\mathrm{a}-\mathrm{c}}$ & $193.7 \pm 2.7^{\mathrm{a}-\mathrm{d}}$ & $28.6 \pm 4.8^{\mathrm{de}}$ & $18.0 \pm 1.1^{\mathrm{de}}$ & $33.4 \pm 4.9^{\mathrm{e}-\mathrm{g}}$ & $3.0 \pm 0.10^{\mathrm{e}}$ & $49.8 \pm 0.1^{\mathrm{ab}}$ & $16.5 \pm 0.7^{\mathrm{ef}}$ & $66.3 \pm 0.7^{\mathrm{de}}$ \\
\hline Razan & $65.9 \pm 1.8^{\mathrm{a}-\mathrm{c}}$ & $181.2 \pm 29.1^{b-d}$ & $32.8 \pm 7.0^{\mathrm{c}-\mathrm{e}}$ & $22.7 \pm 2.7^{\mathrm{a}-\mathrm{c}}$ & $27.5 \pm 7.5^{\mathrm{g}}$ & $3.2 \pm 0.12^{\mathrm{de}}$ & $52.6 \pm 0.3^{\mathrm{a}}$ & $25.4 \pm 4.3^{\mathrm{ab}}$ & $78.0 \pm 4.0^{\mathrm{a}-\mathrm{c}}$ \\
\hline Izeh & $62.9 \pm 1.2^{\mathrm{a}-\mathrm{c}}$ & $287.0 \pm 28.1^{\mathrm{a}-\mathrm{d}}$ & $51.9 \pm 5.1^{\mathrm{a}-\mathrm{d}}$ & $22.0 \pm 3.1^{\mathrm{a}-\mathrm{c}}$ & $28.5 \pm 5.1^{\mathrm{fg}}$ & $3.3 \pm 0.12^{\mathrm{ab}}$ & $49.0 \pm 1.5^{\mathrm{ab}}$ & $17.5 \pm 0.5^{\mathrm{c}-\mathrm{e}}$ & $66.5 \pm 2.0^{\mathrm{de}}$ \\
\hline Babol & $63.1 \pm 4.5^{\mathrm{a}-\mathrm{c}}$ & $400.2 \pm 24.6^{\mathrm{ab}}$ & $57.5 \pm 9.7^{\mathrm{a}-\mathrm{c}}$ & $20.7 \pm 0.5^{\mathrm{a}-\mathrm{e}}$ & $58.7 \pm 9.5^{\mathrm{b}-\mathrm{d}}$ & $3.2 \pm 0.15^{\mathrm{ab}}$ & $50.8 \pm 0.6^{\mathrm{ab}}$ & $22.3 \pm 0.3^{\mathrm{a}-\mathrm{d}}$ & $73.0 \pm 1.0^{\mathrm{a}-\mathrm{e}}$ \\
\hline Tonekabon & $65.8 \pm 2.1^{\mathrm{a}-\mathrm{c}}$ & $301.7 \pm 30.4^{\mathrm{a}-\mathrm{d}}$ & $41.9 \pm 12.6^{\mathrm{b}-\mathrm{e}}$ & $20.3 \pm 0.9^{\mathrm{b}-\mathrm{e}}$ & $48.9 \pm 12.3^{\mathrm{c}-\mathrm{f}}$ & $3.2 \pm 0.15^{\mathrm{ab}}$ & $50.2 \pm 0.9^{\mathrm{ab}}$ & $22.2 \pm 4.0^{\mathrm{a}-\mathrm{d}}$ & $72.3 \pm 4.9^{\mathrm{a}-\mathrm{e}}$ \\
\hline Lourdgan & $56.6 \pm 2.6^{\mathrm{cd}}$ & $142.6 \pm 15.1^{\mathrm{d}}$ & $24.5 \pm 3.7^{\text {de }}$ & $24.3 \pm 1.5^{\mathrm{a}}$ & $22.9 \pm 4.1^{\mathrm{g}}$ & $3.2 \pm 0.07^{\mathrm{a}-\mathrm{c}}$ & $51.8 \pm 0.6^{\mathrm{ab}}$ & $17.8 \pm 1.1^{\mathrm{c}-\mathrm{e}}$ & $69.6 \pm 0.6^{\mathrm{c}-\mathrm{e}}$ \\
\hline Boroujerd & $57.9 \pm 2.4^{\mathrm{b}-\mathrm{d}}$ & $182.7 \pm 15.1^{b-d}$ & $36.7 \pm 3.4^{\mathrm{b}-\mathrm{e}}$ & $20.9 \pm 0.7^{\mathrm{a}-\mathrm{e}}$ & $51.4 \pm 2.9^{\mathrm{c}-\mathrm{e}}$ & $3.2 \pm 0.11^{\mathrm{a}-\mathrm{c}}$ & $51.4 \pm 0.1^{\mathrm{ab}}$ & $23.7 \pm 0.1^{\mathrm{a}-\mathrm{c}}$ & $75.1 \pm 0.2^{\mathrm{a}-\mathrm{d}}$ \\
\hline Kashan & $63.3 \pm 2.0^{\mathrm{a}-\mathrm{c}}$ & $217.2 \pm 71.8^{\mathrm{b}-\mathrm{e}}$ & $40.0 \pm 11.8^{\mathrm{b}-\mathrm{e}}$ & $20.3 \pm 1.0 \mathrm{~b}-\mathrm{e}$ & $48.9 \pm 11.5^{\mathrm{c}-\mathrm{f}}$ & $3.1 \pm 0.13^{\mathrm{ab}}$ & $49.7 \pm 0.9^{\mathrm{ab}}$ & $22.4 \pm 4.5^{\mathrm{a}-\mathrm{d}}$ & $72.2 \pm 5.4^{\mathrm{a}-\mathrm{e}}$ \\
\hline Folad Shahr & $62.9 \pm 5.6^{\mathrm{a}-\mathrm{c}}$ & $158.9 \pm 66.6^{\mathrm{cd}}$ & $21.7 \pm 3.1^{\mathrm{e}}$ & $21.4 \pm 2.0^{\mathrm{a}-\mathrm{e}}$ & $42.0 \pm 2.5^{\mathrm{d}-\mathrm{g}}$ & $3.2 \pm 0.18^{\mathrm{c}-\mathrm{e}}$ & $51.7 \pm 0.8^{\mathrm{ab}}$ & $15.8 \pm 1.2^{\text {ef }}$ & $67.5 \pm 0.4^{\mathrm{de}}$ \\
\hline
\end{tabular}

Different letters indicate a significant difference between the values of pairs of treatment within columns (mean values \pm standard error of mean) at $P \leq 0.01$ 
Table 5. Component matrix of measured agronomic characteristics in 18 populations of Portulaca oleracea

\begin{tabular}{l|r|r|r|r|r}
\hline \multicolumn{1}{c|}{ Variables } & PCA1 & PCA2 & PCA3 & PCA4 & PCA5 \\
\hline Total chlorophyll & 0.787 & 0.132 & 0.125 & 0.566 & -0.040 \\
\hline Protein & -0.710 & -0.144 & 0.235 & 0.384 & 0.016 \\
\hline Chlorophyll b & 0.694 & 0.132 & -0.085 & 0.597 & 0.097 \\
\hline Root fresh weight & 0.619 & 0.180 & 0.089 & -0.212 & 0.573 \\
\hline Chlorophyll a & 0.484 & 0.050 & 0.476 & 0.148 & -0.295 \\
\hline Total dry weight & -0.389 & 0.653 & 0.122 & -0.063 & 0.068 \\
\hline Shoot dry weight & -0.470 & 0.619 & -0.067 & 0.258 & 0.058 \\
\hline Shoot fresh weight & -0.396 & 0.554 & 0.131 & 0.346 & 0.209 \\
\hline Root dry weight & 0.498 & 0.545 & -0.128 & -0.473 & 0.186 \\
\hline Stem diameter & -0.177 & -0.055 & 0.697 & -0.103 & -0.044 \\
\hline Shoot length & 0.206 & 0.451 & 0.534 & -0.300 & -0.427 \\
\hline Root length & 0.370 & -0.339 & 0.411 & -0.032 & 0.205 \\
\hline Branches number & -0.342 & -0.238 & 0.482 & 0.005 & 0.551 \\
\hline Eigen value & 3.327 & 1.882 & 1.538 & 1.405 & 1.044 \\
\hline Variance [\%] & 25.593 & 14.478 & 11.828 & 10.809 & 8.027 \\
\hline Cumulative variance [\%] & 25.593 & 40.072 & 51.900 & 62.709 & 70.736 \\
\hline & & & & & \\
\hline
\end{tabular}

respectively. The highest $(69.3 \pm 15.1 \mathrm{~g}$ per plant $)$ and lowest $(22.9 \pm 21.7$ g per plant) TDW was exhibited by Zanjan, and Chaharmahal and Bakhtiari states, respectively. The protein content in different states varied from 3.0 to $3.3 \mathrm{~g} / \mathrm{ml} \mathrm{FW}$.

The principal component analysis (PCA) revealed five principal components ( $\mathrm{PCs}$ ) with eigenvalue ranging from 0.02 to 3.33 , which made up $70.74 \%$ of the total data variance (Table 5). According to the PCA, 40.07\% of total variance was explained by the first two components. Total chlorophyll content had the highest positive correlation $(>0.787)$ with $\mathrm{PC} 1$, while stem diameter showed the least correlation $(>-0.177)$. The most important characteristic in $\mathrm{PC} 2$ was TDW $(>0.653)$, while chlorophyll a showed the least correlation $(>0.050)$ (Table 5). The UPGMA cluster analysis of the 18 accessions of $P$. oleracea based on the measured agronomic characteristics using the minimum variances (ward method) generated three clusters at the Euclidean distance of 6.82. The first cluster (green cluster) included seven accessions, the second cluster (red cluster) contained eight accessions, and the third cluster (blue cluster) contained three accessions (Fig. 1). The first cluster was associated with the highest mean of TDW (61.2 g per plant) and protein content $(3.24 \mathrm{~g} / \mathrm{ml} \mathrm{FW})$, while the second cluster had the lowest mean of TDW (33.1 g per plant) and protein content $(3.05 \mathrm{~g} / \mathrm{ml} \mathrm{FW})$.

\section{Seed protein patterns and protein-based diversity}

Seed storage proteins of the 18 collected $P$. oleracea accessions from different geographical origins were extracted and separated on SDS-PAGE. The results showed the presence of 15 different types of protein bands ranging from 15 to $100 \mathrm{kDa}$. The results indicated that most of the bands were similar in all accessions. However, two protein bands (13.3\%) with low molecular weight (almost $30 \mathrm{kDa}$ and $40 \mathrm{kDa}$ ) were found to be polymorphic. These two polymorphic proteins included a $40 \mathrm{kDa}$ protein (designated as band "a"), which was absent only in Karaj, Razan, and Kashan accessions, and a $30 \mathrm{kDa}$ protein band (designated as band "b"), which was present in Karaj, Talesh, Bandar Turkman, Razan, Tonekabon, and Kashan accessions (Fig. 2). These protein bands can also serve as potential useful markers for hybridization and breeding programs in future studies.

The UPGMA cluster analysis of the 18 accessions of Portulaca oleracea based on the protein patterns using the minimum variances (ward method) generated three clusters at the Euclidean distance of 4.88 (Fig. 3). The first cluster with green color contained 12 accessions, 


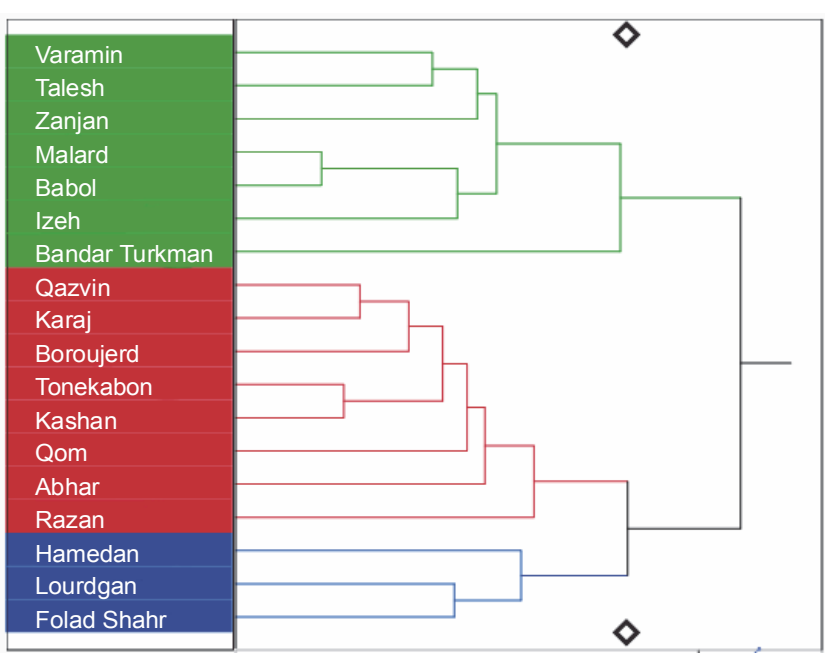

Fig. 1. Dendrogram generated by UPGMA clustering method based on the studied agronomic behavior and photosynthetic pigments in the 18 accessions of Portulaca oleracea

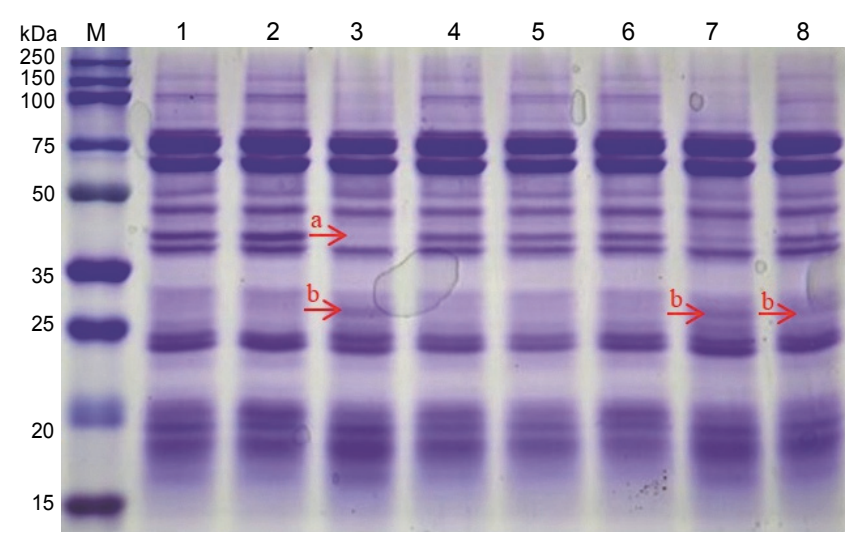

Fig. 2. The seed protein patterns of $P$. oleracea accessions on $12 \%$ polyacrylamide gel; the lane $\mathrm{M}$ represents the protein ladder (Thermo Fisher Scientific, 15-250 kDa), 1) Varamin, 2) Malard, 3) Karaj, 4) Qom, 5) Abhar, 6) Zanjan, 7) Bandar Turkman and 8) Talesh; protein samples were loaded with equal amount of $15 \mu \mathrm{g}$ of proteins

indicating close similarity among most accessions; the second cluster (the red cluster) contained 3 accessions; and the third cluster (the blue one) also comprised 3 accessions. Karaj, Razan, and Kashan accessions, which were lacking protein "a", were located separately in the third cluster. The cluster analysis indicated that the accessions possessing protein "b" are much more related together than those lacking this protein and were located in the second cluster (Fig. 3).

\section{Altitude and proteomic association of the accessions}

Grouping the accessions based on the presence or absence of the polymorphic proteins and comparing the

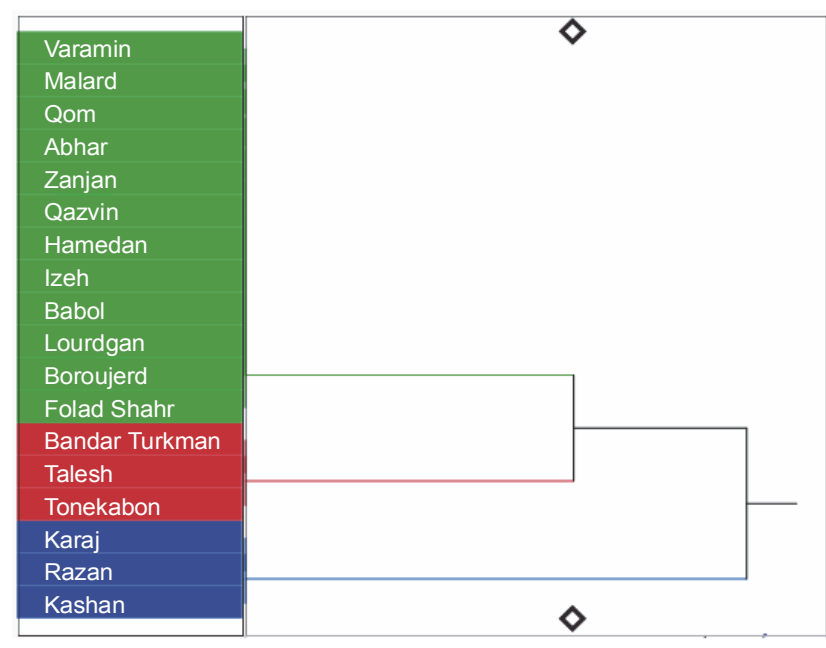

Fig. 3. Dendrogram generated by UPGMA clustering method based on seed storage protein patterns showing the phylogenetic relationships of the 18 accessions of $P$. oleracea

groups in terms of the altitude data using independent sample t-test showed significant differences between the groups (Table 5). The results revealed that the presence or absence of these proteins might be related to the altitude of geographical origins. The mean of altitude in accessions containing protein "a" was lower than that for accessions lacking this protein, while the mean of altitude in accessions containing protein "b" was higher than that for accessions lacking this protein (Table 6). In other words, protein "a" was produced by accessions growing in low altitude areas, while protein "b" was produced by accessions growing in high altitude areas.

\section{Relationships between accessions based on agronomic traits, photosynthetic pigments, and protein data}

The cluster analysis based on agronomic traits, photosynthetic pigments, and protein data provided evidence to prove the existence of differences among the accessions. Grouping the accessions based on the presence or absence of the polymorphic proteins and comparing the groups in terms of TDW, chlorophyll b content, and total chlorophyll content using independent samples t-test indicated significant differences between the groups (Table 7). The mean of TDW in accessions containing protein "a" was higher than that for accessions lacking this protein, while the mean of TDW in accessions containing protein "b" was lower than that for accessions lacking this protein. The mean of chlorophyll $\mathrm{b}$ and total chlorophyll content in accessions containing protein "a" was lower than that for accessions lacking this protein, 
Table 6. The comparing the two groups of Portulaca oleracea accessions based on presence and absence of protein "a" and protein " $\mathrm{b}$ " in terms of altitude of geographical origins using $t$-test

\begin{tabular}{c|c|c|c|c|c|c|c}
\hline \multirow{2}{*}{ Variable } & \multirow{2}{*}{ Groups } & \multicolumn{3}{|c|}{ Protein “a” } & \multicolumn{3}{c}{ Protein “b” } \\
\cline { 3 - 8 } & & $\mathrm{N}$ & mean \pm SEM & sig & $\mathrm{N}$ & mean \pm SEM & \multirow{2}{*}{ sig } \\
\hline \multirow{2}{*}{ Altitude } & presence & 45 & $962.1 \pm 108.2$ & \multirow{2}{*}{0.017} & 21 & $1285.6 \pm 136.1$ & \multirow{2}{*}{0.031} \\
\cline { 2 - 4 } \cline { 3 - 7 } & absence & 9 & $1378.7 \pm 121.4$ & & 33 & $869.9 \pm 121.3$ & \\
\hline
\end{tabular}

Table 7. The comparing the two groups accessions of Portulaca oleracea based on presence and absence of protein "a" in terms of agronomic traits using $t$-test

\begin{tabular}{|c|c|c|c|c|c|c|c|c|}
\hline \multirow{2}{*}{ Protein } & \multirow{2}{*}{ Groups } & \multirow{2}{*}{$\mathrm{N}$} & \multicolumn{2}{|c|}{ Total dry weight } & \multicolumn{2}{|c|}{ Chlorophyll b } & \multicolumn{2}{|c|}{ Total chlorophyll } \\
\hline & & & mean \pm SEM & sig & mean \pm SEM & sig & mean \pm SEM & sig \\
\hline \multirow{2}{*}{ Protein "a" } & presence & 45 & $51.2 \pm 2.9$ & \multirow{2}{*}{0.034} & $20.0 \pm 0.9$ & \multirow{2}{*}{0.039} & $70.8 \pm 1.0$ & \multirow{2}{*}{0.043} \\
\hline & absence & 9 & $42.0 \pm 3.8$ & & $24.5 \pm 1.9$ & & $76.0 \pm 2.2$ & \\
\hline \multirow{2}{*}{ Protein "b" } & presence & 21 & $43.2 \pm 3.4$ & \multirow{2}{*}{0.041} & $22.9 \pm 1.5$ & \multirow{2}{*}{0.037} & $73.4 \pm 1.9$ & \multirow{2}{*}{0.049} \\
\hline & absence & 33 & $53.8 \pm 3.4$ & & $19.4 \pm 0.9$ & & $70.5 \pm 1.0$ & \\
\hline
\end{tabular}

while the mean of chlorophyll $\mathrm{b}$ and total chlorophyll content in accessions containing protein " $b$ " was higher than that for accessions lacking this protein (Table 6). In other words, the presence of protein "a" caused an increase in dry weight and the presence of protein " $b$ " caused a decrease in dry weight, while the presence of protein "a" caused a decrease in the chlorophyll content and the presence of protein "b" caused an increase in the chlorophyll content.

\section{Discussion}

The study of biochemical and biomass differences among plant species of different geographical origins is important to obtain essential baseline data and to enable a better understanding of conservation, management, and collection strategies for germplasm of these species (Lou et al., 2015). In the current study, agronomic traits and protein patterns revealed significant differences among the studied purslane accessions; these results agreed well with the findings of Alam et al. (2014), who showed a high genetic diversity among purslane populations, which could be due to free pollination and the possibility of pollen transfer between the species (Wickramasinghe et al., 2010).

Marker techniques, ecotypes, and their origins are important parameters that affect the observed genetic polymorphisms in plants (Binova et al., 2020). Protein pattern analysis and clustering of accessions based on protein patterns are useful in plant breeding programs. The gel analysis detected two polymorphic protein bands sized approximately $40 \mathrm{kDa}$ (band "a"), which was absent in Karaj, Razan, and Kashan accessions, and $30 \mathrm{kDa}$ (band "b"), which was present in Karaj, Qazvin, Bandar Turkman, Razan, Lourdgan, Kashan, and Folad Shahr accessions. Three clusters were observed in proteinbased data analysis. Karaj, Razan, and Kashan accessions, which lacked protein "a", were located separately in the third cluster, and the accessions possessing protein " $b$ " were much more related together than those lacking this protein and were located in the second cluster.

In Iran, purslane accessions are distributed in various geographical regions with different climates, which results in adaptation to ecological factors and genetic variation. Climate plays an important role in local adaptation of the plant species and genetic diversity of the plant populations (Mosca et al., 2012). In the present study, grouping the accessions based on the presence or absence of these protein bands and comparing the groups according to the altitude of geographical origins, TDW, and chlorophyll $\mathrm{b}$ and total chlorophyll content using independent samples $t$-test showed significant differences between the groups (Tables 5 and 6 ). The relationship between protein patterns and geographical origins indicated the impact of ecological conditions on adaptation and differentiation of purslane accessions; 
this result agreed well with the findings of Zhao et al. (2006) on Stipa grandis populations and of Huang et al. (2016) on Caragana microphylla, who reported influence of some climatic factors on genetic diversity in these plants. Our results showed the explicit impact of seed proteins in improving (protein b) or decreasing (protein a) agronomic traits and photosynthetic pigments. For instance, the absence of protein "a" and presence of protein " $b$ " in Karaj, Razan, and Kashan accessions resulted in lower TDW and lower chlorophyll content than that in other accessions (Table 4). Thus, it could be concluded that the agronomic variation observed in these accessions might be due to the specific protein profiling. There is little information on the relationship between protein patterns produced by seed storage proteins in electrophoresis, agronomic characteristics, and geographical origins. Talei et al. (2014) studied Andrographis paniculata accessions and reported that the polymorphic proteins effectively differentiated the morphological characteristics and phylogenetic relationships among the accessions and these proteins acted as activator agents for agronomic characteristics such as TDW. Andrews et al. (2006) in a study on tobacco (Nicotiana tabacum) without emphasizing on a specific protein claimed that generally, shoot protein concentration influences shoot and root growth. A linear regression model incorporating leaf soluble protein concentration and plant dry weight has also been reported. Victor et al. (2010) in a study on Vitis riparia Michx. grapevines reported that day length could act as an abiotic factor for alteration of protein patterns and can lead to a different expression pattern of agronomic characteristics in plants. Gherekhloo et al. (2020) studied Phalaris minor populations and reported a high genetic similarity among the populations in different regions. Bahraminrjad and Mohammadinejad (2013) reported that different cultivation conditions influenced the agro-morphological traits of cumin ecotypes.

There is little information on how the detected protein patterns could be directly attributed to the agronomic characteristics, although recent studies have tended to make a more accurate link between specific proteins and agronomic diversity (Hanada et al., 2009). Our results agreed well with the findings of Akhila and Beevy (2011) who used protein patterns as markers to describe the morphological variation between the Sesamum species as it was noted that a speci c protein was the unique feature of the cultivated species, whereas the two other protein bands were characteristics of the wild species. Interestingly, sometimes, a speci c protein seems to simultaneously play the role of a repressor and an activator in plants' architecture (He et al. 2010). Notably, in our present study, these roles were performed by separate proteins, where in the suppressive role was performed by protein "a" for TDW in some accessions, whilst protein " $b$ " played the activator role for this trait in different accessions. The results also indicated that the simultaneous presence of the activator and suppressor proteins in an accession could lead to an unstable increase in different morphological traits. The results of the present study suggest that the protein variation among the accessions of $P$. oleracea can be used as an effective strategy in plant breeding programs. In addition, the differences observed among the accessions are quite important for the development of the $P$. oleracea bank and may be used in hybridization and breeding programs. Nevertheless, there are few questions that need to be addressed: which mechanism could lead to an increase or decrease in TDW? Can the altitude of geographical origins be effective in the synthesis of these proteins? What is the biochemical combination of these proteins? Are these proteins encoded by a specific gene or by a couple of genes? And finally, are these proteins probably associated with the photosynthetic pigment content of the plant?

\section{Conclusions}

Although seed proteins, agronomic traits, and photosynthetic pigments were used for providing data to study the diversity and inter-relationships of $P$. oleracea accessions, our main purpose was to find the association between protein patterns and the altitude of geographical origins, agronomic traits, and photosynthetic pigment content. The two polymorphic protein bands of $40 \mathrm{kDa}$ (protein "a") and $30 \mathrm{kDa}$ (protein "b") effectively diversified the agronomic behavior, photosynthetic pigments, and phylogenetic relationships among the purslane accessions. Interestingly, protein "a" was produced in accessions growing in low altitude areas and played a suppressive role for TDW, while protein " $b$ " was produced in accessions growing in high altitude areas and served as an activator agent for this trait. Overall, the outcomes of the present study indicated that the polymorphic pro- 
teins effectively diversified the agronomic behavior and photosynthetic pigments among the purslane accessions. These findings suggest that these proteins should be sequenced and perfectly established for further proteomic analyses. Finally, these proteins can be used for hybridization to generate useful recombinants in segregating generations and in improving breeding varieties of $P$. oleracea.

\section{References}

Aharizad S., Rahimi M.H., Moghadam M., Mohebalipour N. (2012) Study of genetic diversity in lemon balm (Melissa officinalis $L$.) populations based on morphological traits and essential oils content. Ann. Biol. Res. 3(12): 5748-5753.

Akhila H., Beevy S.S. (2011) Morphological and seed protein characterization of the cultivated and the wild taxa of Sesamum L. (Pedaliaceae). Plant Syst. Evol. 293(1): 65-70.

Alam M.A., Juraimi A.S., Rafii M., Hamid A.A., Arolu I.W., Latif M. (2015) Application of EST-SSR marker in detection of genetic variation among purslane (Portulaca oleracea L.) accessions. Brazil. J. Bot. 38(1): 119-129.

Alam M.A., Juraimi A.S., Rafii M., Hamid A.A., Uddin M.K., Alam M., Latif M. (2014) Genetic improvement of purslane (Portulaca oleracea L.) and its future prospects. Mol. Biol. Rep. 41(11): 7395-7411.

Andrews M., Raven J., Lea P., Sprent J. (2006) A role for shoot protein in shoot-root dry matter allocation in higher plants. Ann. Bot. 97(1): 3-10.

Arnon A. (1967) Method of extraction of chlorophyll in the plants. Agron. J. 23: 112-121.

Asante I., Offei S., Addy R., Carson A. (2009) Phenotypic and seed protein analysis in 31 Lima bean (Phaseolus lunatus) accessions in Ghana. West Afr. J. Appl. Ecol. 12(1): 1-10.

Bahraminejad A., Mohammadinejad G. (2013) Use of microsatellite markers for molecular characterization of cumin (Cuminum cyminum L.) ecotypes. Iran. J. Genet. Plant Breed. 2(1): 35-41.

Bínová Z., Korecký J., Dvořák J., Bilý J., Zádrapová D., Jansa V., Lstibưrek M. (2020) Genetic structure of norway spruce ecotypes studied by SSR markers. Forests 11(1): 110.

Bradford M.M. (1976) A rapid and sensitive method for the quantitation of microgram quantities of protein utilizing the principle of protein-dye binding. Analyt. Bioch. 72(1-2): 248-254.

Danaeipour Z., Fotokian M.H., Talei D. (2019) Genetic structure and relationships among Melissa officinalis accessions using AFLP markers. Biocatal. Agric. Biot. 22: 101416.

El-Bakatoushi R. (2010) Genetic diversity of winter wheat (Triticum aestivum L.) growing near a high voltage transmission line. Roman. J. Biol. Plant Biol. 55(2): 71-87.

Ernst M., Putnová L., Štohl R., Matoušková J. (2017) Comparison of Czech and Latvian beaver population by microsatellite analysis and genetic differences between castor fiber and Castor canadensis. Transyl. Rev. 25(21): 5339-5349.
Gherekhloo J., Alcantara-De La Cruz R., Osuna M., Sohrabi S., Prado R. (2020) Assessing genetic variation and spread of Phalaris minor resistant to ACcase inhibiting herbicides in Iran. Planta Danin. 38: 1-9.

Hanada K., Kuromori T., Myouga F., Toyoda T., Shinozaki K. (2009) Increased expression and protein divergence in duplicate genes is associated with morphological diversification. PLoS Gen. 5(12): e1000781.

Hassan M., Badr A., Mustafa A., El-Galaly M., Mobarak A. (2003) Genetic diversity among Mentha populations in Egypt as reflected by morphological and protein electrophoretic variations. J. Agri. Food Chem. 2: 269-286.

He C., Tian Y., Saedler R., Efremova N., Riss S., Khan M.R., Yephremov A., Saedler H. (2010) The MADS-domain protein MPF1 of Physalis floridana controls plant architecture, seed development and flowering time. Planta 231(3): 767-777.

Huang J.F., Zhang M.L., Cohen J.I. (2013) Phylogenetic analysis of Lappula Moench (Boraginaceae) based on molecular and morphological data. Plant Syst. Evol. 299(5): $1-14$.

Huang W.-D., Zhao X.-Y., Zhao X., Li Y.-L., Pan C.-C. (2016) Environmental determinants of genetic diversity in Caragana microphylla (Fabaceae) in northern China. Bot. J. Linn. Soc. 181(2): 269-278.

Khurshid H., Rabbani M.A. (2012) Comparison of electrophoretic protein profiles from seed of different oilseed Brassica cultivars. J. Publ. Health Biol. Sci. 1(2): 36-42.

Kutka Hlozakova T., Gregova E., Vivodik M., Gálová Z. (2016) Genetic diversity of European cultivars of common wheat (Triticum aestivum L.) based on RAPD and protein markers. J. Centr. Eur. Agric. 17(4): 957-969.

Lou Y., Hu L., Chen L., Sun X., Yang Y., Liu H., Xu Q. (2015) Association analysis of simple sequence repeat (SSR) markers with agronomic traits in tall fescue (Festuca arundinacea Schreb.). PLoS One 10: e0133054.

Masoodi M.H., Ahmad B., Mir S.R., Zargar B.A., Tabasum N. (2011) Portulaca oleracea L. a review. J. Pharm. Res. 4(9): 3044-3048.

Mosca E., Eckert A., Di Pierro E., Rocchini D., La Porta N., Belletti P., Neale D. (2012) The geographical and environmental determinants of genetic diversity for four alpine conifers of the E uropean A lps. Mol. Ecol. 21(22): 5530-5545.

Movahedian A., Ghannadi A., Vashirnia M. (2007) Hypocholesterolemic effects of purslane extract on serum lipids in rabbits fed with high cholesterol levels. Int. J. Pharm. 3(3): 285-289.

Mustafa A., Badr A., El-Galaly M.A., Mobarak A.A., Hassan M.G. (2006) Genetic diversity among Ocimum populations in Egypt as reflected by morphological, seed proteins and isozyme polymorphism. Int. J. Bot. 2(3): 261-269.

Okafor I.A., Ayalokunrin M.B., Orachu L.A. (2014) A review on Portulaca oleracea (purslane) plant-its nature and biomedical benefits. Int. J. Biomed. Res. 5(2): 75-80.

Okpul T., Mace E., Godwin I., Singh D., Wagih M. (2005) Evaluation of variability among breeding lines and cultivars of taro (Colocasia esculenta) in Papua New Guinea using 
ISSR fingerprinting and agro-morphological characterization. Plant Gen. Res. Newslett. 143: 8.

Sharma D.B., Krishna K.R. (2017) Genetic diversity in Cowpea [Vigna unguiculata (L.) Walp.] accessions using protein profiling. Int. J. Pure Appl. Biosci. 5(2): 491-496.

Talei D., Mihdzar A.K., Khanif M.Y., Saad M.S., Valdiani A.R. (2011) Effects of different surface sterilizers on seed germination and contamination of king of bitters (Andrographis paniculata Nees.). Amer.-Euras. J. Agr. Environ. Sci. 10: 639-643.

Talei D., Valdiani A., Abdullah M.P. (2014) Impact of protein diversification on morphometric behavior of Andrographis paniculata Nees. Plant Syst. Evol. 300: 1003-1010. doi: 1010.1007/s00606-00013-00938-Z

Talei D., Valdiani A., Puad M. (2013) An effective protein extraction method for two-dimensional electrophoresis in the anticancer herb (Andrographis paniculata Nees.). Biot. Appl. Bioch. 60(5): 521-526. doi: 2010.1155/2013/319047
Victor K.J., Fennell A.Y., Grimplet J. (2010) Proteomic analysis of shoot tissue during photoperiod induced growth cessation in V. riparia Michx. grapevines. Prot. Sci. 8(1): 44.

Wickramasinghe P., Harrison D.K., Johnston M.E. (2010) Reproductive biology and intergeneric breeding compatibility of ornamental Portulaca and Calandrinia (Portulacaceae). Austr. J. Bot. 57(8): 697-707.

Zhao N., Gao Y., Wang J., Ren A., Xu H. (2006) RAPD diversity of Stipa grandis populations and its relationship with some ecological factors. Acta Ecol. Sinica 26(5): 1312-1318.

Zhou Y.X., Xin H.L., Rahman K., Wang S.J., Peng C., Zhang H. (2015) Portulaca oleracea L.: a review of phytochemistry and pharmacological effects. BioMed Res. Int. 2015: 925631. 